\title{
The Effects and Characteristics of Musculoskeletal Pain on Quality of Life in Geriatric Patients
}

\author{
(1) Nilay Şahin1, (1) Gül Devrimsel2, (1) Ali Yavuz Karahan33, (1) Serdar Sargın4 \\ ${ }^{1}$ Balıkesir University Faculty of Medicine, Department of Physical Medicine and Rehabilitation, Balıkesir, Turkey \\ ${ }^{2}$ Recep Tayyip Erdoğan University Faculty of Medicine, Department of Physical Medicine and Rehabilitation, Rize, Turkey \\ ${ }^{3}$ Uşak University Faculty of Medicine, Department of Physical Medicine and Rehabilitation, Uşak, Turkey \\ ${ }^{4}$ Balıkesir University Faculty of Medicine, Department of Orthopaedic and Traumatology, Balıkesir, Turkey
}

\begin{abstract}
Objective: This study aimed to is to compare the pain levels, quality of life, and depression levels of geriatric patients and non-geriatric patients due to musculoskeletal pain.

Materials and Methods: $300 \mathrm{GP}$ and 250 NGP were included in this cross-sectional study. The inclusion criteria were as follows: patients aged between 18-90 years, those suffering from musculoskeletal pain, and those with a pain severity between 2 and 8 points agreed to participate in the study. Visual pain scale (VPS) was used for the assessment of pain severity. The quality of life was assessed by Short form-36 (SF-36). The Beck depression scale (BDS) was used to assess depression status.

Results: In the GP group, the prevalence of additional comorbidities, frequency of drug use, and the number of painful sites in the musculoskeletal system were more frequent from those of the NGP group ( $p<0.05$ for all). Myofascial pain syndrome and fibromyalgia syndrome were significantly more frequent in the NGP group ( $p<0.05$ for both). There were statistically significant differences in the physical role, pain, social, energy, and mental status subgroup scores of the VPS, SF-36, and BDS in the GP group compared to the NGP group ( $p<0.05$ for all).

Conclusion: This cross-sectional study suggests that musculoskeletal problems are becoming increasingly considerable that can significantly impact the quality of life in the geriatric population at the end of life. Obtained results highlight the high prevalence and severity of musculoskeletal symptoms that were assimilated into a patient's daily life.
\end{abstract}

Keywords: Musculoskeletal pain, quality of life, geriatric, depression

\section{Introduction}

Aging is a natural process expected for the individual, and the reserve capacities of organs and their ability to adapt to environmental factors reduce with aging (1). Like all organs during this period, there are also changes in the musculoskeletal system. Musculoskeletal system disorders such as osteoporosis, chronic back pain, osteoarthritis, fibromyalgia, Myofascial Pain syndrome, tendinitis, and epicondylitis are commonly encountered in the elderly (2-4). Chronic musculoskeletal pain is prevalent, and disability occurs in at least one-quarter of the elderly $(5,6)$. It is crucial for an elderly individual to be independent at home and in society and to assess their functional capacity (7). Cartilage degeneration, decrease in total muscle mass, and reduction in functional mobility are seen with aging. On the other hand, the quality of life deteriorates in the elderly population $(8,9)$.

This study aimed to is to compare the pain levels, quality of life, and depression levels of geriatric patients (GP) and nongeriatric patients (NGP) due to musculoskeletal pain.

\section{Materials and Methods}

Three hundred GP (65-90 age) and 250 NGP who admitted

Address for Correspondence: Serdar Sargın MD, Balıkesir University Faculty of Medicine, Department of Orthopaedic and Traumatology, Balıkesir Turkey

Phone: +90 5073041370 E-mail: drserdarsargin@yahoo.com ORCID: orcid.org/0000-0003-4939-8745

Received: Jan 04, 2020 Accepted: Mar 09, 2020

Cite this article as: Şahin N, Devrimsel G, Karahan AY, Sargın S. The Effects and Characteristics of Musculoskeletal Pain on Quality of Life in Geriatric Patients. Eur J Geriatr Gerontol 2020;2(1):13-17

๑Copyright 2020 by the Academic Geriatrics Society / European Journal of Geriatrics and Gerontology published by Galenos Publishing House. 
to physical therapy and rehabilitation outpatient clinic were included in this cross-sectional study. The demographic characteristics, functional status, and emotional status of the participants were questioned. The Institutional Review Board of Selçuk University approved this study (2011-022).

The inclusion criteria were as follows: patients aged between 18-90 years, those suffering from musculoskeletal pain, those with a pain severity between two and eight points (on a Visual Analog scale of $10 \mathrm{~cm}$ ), and agreed to participate in the study. Musculoskeletal system pain was evaluated according to anamnesis and physical examination, and patients were included accordingly. The definition of musculoskeletal pain is; it is a pain that patients feel in their joints, ligaments, tendons, and muscles, and there are physical examination findings for these areas $(10,11)$.

Patients who were heavy bodyworkers, those with uncontrolled chronic disease (hypertension, Diabetes Mellitus, atrial fibrillation, renal insufficiency, multiple sclerosis), with a history of musculoskeletal surgery for any reason and those with any malignancy either in remission or not were excluded from the study.

Visual Pain scale (VPS) was used for the assessment of pain severity. On the VPS, there are numbers placed from zero to 10 on a $10 \mathrm{~cm}$ line. No pain is scored as zero; the most severe pain ever felt is 10 (12). The patient was asked to mark the severity of the general body pain on this line.

The quality of life was assessed by Short form-36 (SF-36). The SF-36 is a questionnaire consisting of 8 sub-groups and a total of 36-question to measure the overall quality of life. It is filled in by the patient him/herself. SF-36 has eight subfields: general health, physical function, physical role, pain, vitality, social function, emotional role, and mental health. The total score ranges from 0-to-100. Zero reports the worst health condition, 100 reports the best condition. The validity and reliability of the Turkish version were done $(13,14)$.

The Beck depression scale (BDS) was used to assess depression status. In adults, this is a self-assessment scale developed to measure the risk of depression, the severity of depressive symptoms, and change in intensity. It is a measure that consists of 21-questions developed to determine the depression level of the patients. Each question is scored from zero to three points in an increasing manner, and the total score ranges between zero and 63 (15). The higher total score indicates severe depression. The validity and reliability studies in our country were conducted by Hisli (16).

\section{Statistics}

The SPSS for Windows 11.0 software package (Chicago, IL) was used for the statistical evaluation of the data. The conformity of continuous variables with normal distribution was investigated using the Kolmogorov-Smirnov test. All variables were distributed normally. Descriptive data were presented as a mean \pm standard deviation. Demographic and clinical characteristics were compared using the chi-square test. Within-group and between-group differences were investigated. The independent samples test was used to compare the two groups. The pairedsamples t-test was used to analyze the differences between the baseline and after treatment values. A p-value of less than 0.05 was considered statistically significant.

\section{Results}

The mean age of the GP group is $70.26 \pm 4.81$ years, and the mean age of NGP is $32.94 \pm 10.81$ years. The male-to-female ratio was $39 \%-61 \%$ in the GP group, while it was 26\% - 74\% in the NGP group (Table 1). In the GP group, the prevalence of additional comorbidities, frequency of drug use, and the number of painful sites in the musculoskeletal system were significantly higher than those of the NGP group ( $p<0.05$ for all). Myofascial pain syndrome and fibromyalgia syndrome were significantly more

\begin{tabular}{|c|c|c|c|}
\hline $\begin{array}{l}\text { Table } 1 \text {. Baseline charac } \\
\text { and non-geriatric group }\end{array}$ & ristics of i & iduals in & geriatric \\
\hline & $\begin{array}{l}\text { GP } \\
(n=300)\end{array}$ & $\begin{array}{l}\text { NGP } \\
(n=250)\end{array}$ & $\mathbf{p}$ \\
\hline Age (Mean \pm SD) & $70.26 \pm 4.81^{*}$ & $32.94 \pm 10.81$ & $<0.001$ \\
\hline Gender (\%) & & & \\
\hline Male & 38.9 & 25.8 & - \\
\hline Female & 61.1 & 74.2 & - \\
\hline BMI $\left(\mathrm{kg} / \mathrm{m}^{2}\right)($ Mean $\pm \mathrm{SD})$ & $30.1 \pm 2.9$ & $28.9 \pm 2.6$ & - \\
\hline $\begin{array}{l}\text { Comorbid conditions } n \\
(\%)\end{array}$ & & & $<0.001$ \\
\hline Hypertension & $132(44)$ & $15(6)$ & - \\
\hline Diabetes & $96(32)$ & $12(4.8)$ & - \\
\hline Anxiety and/or depression & $93(31)$ & $45(18)$ & - \\
\hline Cerebrovascular disease & $58(19.3)$ & $2(0.8)$ & - \\
\hline COPD & $68(22.6)$ & $8(3.2)$ & - \\
\hline Renal disease & $51(17)$ & $5(2)$ & - \\
\hline Liver disease & $38(12.6)$ & $5(2)$ & - \\
\hline Frequency of falls & $102(34)$ & $3(1.2)$ & $<0.001$ \\
\hline
\end{tabular}

Table 2. Musculoskeletal disorders

\begin{tabular}{|l|l|l|l|}
\hline & \multicolumn{1}{|l|}{$\begin{array}{l}\text { GP } \\
(\mathbf{n = 3 0 0 )}\end{array}$} & $\begin{array}{l}\text { NGP } \\
(\mathbf{n = 2 5 0 )}\end{array}$ & p \\
\hline Fibromyalgia (\%) & 9.3 & $19.3^{*}$ & $<0.001$ \\
\hline Myofascial Pain syndrome (\%) & 47.5 & $62.9^{*}$ & $<0.001$ \\
\hline $\begin{array}{l}{ }^{*} \mathrm{p}<0.001, \text { GP: Geriatric patients, NGP: Non-geriatric patients, n: Number of the } \\
\text { patients }\end{array}$ \\
\hline
\end{tabular}


frequent in the NGP group ( $<<0.05$ for both) (Table 2). There were statistically significant differences in the physical role, pain, social, energy, and mental status subgroup scores of the VPS, SF-36, and BDS in the GP group compared to the NGP group ( $p<0.05$ for all) (Table 3,4).

\begin{tabular}{|c|c|c|c|}
\hline VPS and BDS & GP $(n=300)$ & NGP $(n=250)$ & p \\
\hline \multicolumn{4}{|l|}{ VPS } \\
\hline At rest & $4.27 \pm 1.89$ & $3.85 \pm 2.72$ & - \\
\hline At exercise & $6.28 \pm 1.76^{*}$ & $5.24 \pm 2.71$ & $<0.001$ \\
\hline At night & $4.45 \pm 2.66^{*}$ & $2.50 \pm 3.05$ & $<0.001$ \\
\hline BDS & $15.56 \pm 7.36^{*}$ & $14.14 \pm 10.05$ & $<0.001$ \\
\hline
\end{tabular}

GP: Geriatric patients, NGP: Non-geriatric patients, VPS: Visual pain scale, BDS: Beck Depression scale, ${ }^{*} p<0.001$

\begin{tabular}{|l|l|l|l|}
\hline \multicolumn{4}{|l}{ Table 4. Short form-36 quality of life questionnaire scoring } \\
\hline SF-36 & $\begin{array}{l}\text { GP } \\
\text { (n=300) }\end{array}$ & NGP \\
(n=250) & \\
\hline Physical functioning & $69.06 \pm 50.47$ & $69.24 \pm 26.17$ & - \\
\hline $\begin{array}{l}\text { Role limitations due to } \\
\text { physical health }\end{array}$ & $25.54 \pm 36.87^{*}$ & $48.55 \pm 42.58$ & $<0.001$ \\
\hline Pain & $49.72 \pm 15.26^{* *}$ & $45.45 \pm 19.48$ & $<0.05$ \\
\hline General health & $50.83 \pm 19.36$ & $53.61 \pm 14.37$ & - \\
\hline Energy & $38.81 \pm 18.18^{*}$ & $48.60 \pm 13.77$ & $<0.001$ \\
\hline Social functioning & $41.17 \pm 19.61^{*}$ & $46.91 \pm 16.70$ & $<0.001$ \\
\hline $\begin{array}{l}\text { Role limitations due to } \\
\text { emotional problems }\end{array}$ & $47.84 \pm 46.16$ & $50.18 \pm 42.37$ & - \\
\hline Emotional well-being & $55.52 \pm 19.50^{*}$ & $43.05 \pm 15.29$ & $<0.001$ \\
\hline $\begin{array}{l}\text { GP: Geriatric patients, NGP: Non-geriatric patients, }{ }^{*} \mathrm{p}<0.001,{ }^{* *} \mathrm{p}<0.05, \\
\text { form-36 SF-36: Short }\end{array}$ \\
\hline
\end{tabular}

\section{Discussion}

Aging is the most important factor that leads to a decrease in quality of life relevant to biological, social, and psychological dimensions. Chronic diseases and disability are more common in GP than in other age groups $(17,18)$. The level of activity is restricted by disability at the geriatric age $(19,20)$. Restriction in daily life activities harms the quality of life. In previous studies, aging has been found to hurt the quality of life $(21,22)$. On the other hand, another study reported that there was no relationship between age and quality of life and that there was a decrease in quality of life due to additional factors in the elderly (1). In our study, we found that the physical role of life quality, pain, social, energy, and mental status parameters were more negatively affected in the GP group.

The prevalence of pain in the geriatric population is seen in 18$57 \%$ (23) and has an important place in health expenditures (24). In a previous study, it was found that musculoskeletal pain is common in the elderly and that the quality of life is lower in elder people suffering from pain (25). It has also been reported that elderly women have lower quality of life who stay in nursing homes and have chronic musculoskeletal pain (26). Brown et al. (27) found that in the geriatric population more than $90 \%$ of the elderly experience pain. It has also been observed that the frequency of pain complaint increases in the elderly who are at the last period of their lives (28). However, Woo et al. (29) reported that the prevalence of musculoskeletal pain does not change after 70 years of age, while Bergman et al. (30) reported a decrease in the frequency of pain complaint after age 65 years. In our study, the prevalence of pain in elderly individuals was found to be high.

Soft tissue problems are common due to physiological changes in the geriatric period (31). Fibromyalgia, rotator cuff rupture, adhesive capsulitis and Compression syndrome are common soft tissue problems (32). A previous study has reported that myofascial pain syndrome takes place as the second among the most common causes of soft tissue problems (2). However, in our study, we found that soft tissue pathologies were more frequent in the NGP group.

Chronic musculoskeletal pain in elderly patients is a frequent geriatric consultation and admission cause, and opioid and non-opioid analgesics are widely used in the treatment. On the other hand, with increasing drug use, problems such as drug side effects and increased drug costs arise $(33,34)$. One previous study has reported that systemic pathologies are more frequently encountered in the elderly population (2). In our study, we found that analgesic medication was used more commonly in the GP group, and thyroid disease, Diabetes Mellitus, hypertension, and cardiovascular system disease were more frequently observed.

Falls are one of the major causes of death in geriatric populations and results in an increase in health expenditures (35). There is a reduction in the strength of tendons and ligaments by aging and this causes increase in joint laxity (9). $25-55 \%$ of the geriatric population has fear of falling, therefore they restrict their activities. Skeletal muscle pain and activity restriction may cause further weakness in the muscles $(36,37)$. It was found that there were more falls in patients with chronic pain (38). Environmental factors and musculoskeletal disorders have an adverse effect on balance $(39,40)$. In our study, we found that the frequency of falls was higher in the GP group.

Depression is common in the geriatric population (41). Pain is a significant risk factor for depression. Miu et al. (42) have reported that depression is more common in elders suffering from pain. IIlhan et al. (43) found the frequency of depression as $48.2 \%$ among the elderly living in nursing homes. In another study, it was reported that this ratio was $41 \%(44,45)$. In our study, we found that depression is more common in the geriatric population. 
With aging, the number of additional illnesses and associated drug use, risk of falls, pain intensity, and the number of painful areas in the musculoskeletal system increase significantly. Despite the increase in the number of painful sites, the prevalence of soft-tissue rheumatism is lower in elderly patients. Depression is more common in the elderly as a reflection of age-related complaints and complaints of pain, and the quality of life is deteriorating.

\section{Limitations of the Study}

Although the sample size was calculated before the study, the number of patients whose results were evaluated can be considered low.

\section{Conclusion}

This cross-sectional study suggests that musculoskeletal problems are becoming increasingly considerable that can significantly impact the quality of life in the geriatric population at the end of life. Obtained results highlight the high prevalence and severity of musculoskeletal symptoms that were assimilated into a patient's daily life. Antecedence for further studies include qualitative research, should provide evidence-based treatment models for musculoskeletal pain-related patient priorities.

\section{Ethics}

Ethics Committee Approval: The study was approved by the ethics committee of Selçuk University (2011/022).

Informed Consent: Informed consent was obtained.

Peer-review: Internally peer-reviewed.

\section{Authorship Contributions}

Consept: G.D., Design: N.Ş., A.Y.K., Data Collection and/or Processing: N.Ş., A.Y.K., S.S., Analysis and/or Interpretation: G.D., A.Y.K., Literature Research: N.Ş., A.Y.K., S.S., Writing: S.S., G.D.

Conflict of Interest: No conflict of interest was declared by the authors.

Financial Disclosure: The authors declared that this study received no financial support.

\section{References}

1. Akyol Y, Durmuş D, Doğan C, Bek Y, Cantürk F. Quality of life and level of depressive symptoms in the geriatric population. Archives of Rheumatology. 2010;25:165-173.

2. Çakmak B, Aydın F, Aktaş I, Akgün K, Eryavuz M. Geriatrik hastalarda kasiskelet sistemi hastalıkları. Türk Geriatri Dergisi. 2004;7:221-224.

3. Seçkin Ü, Borman P, Bodur H. Fizik tedavi ve rehabilitasyon polikliniğine başvuran yaşııların tanısal dağılımı. Turkish Journal of Geriatrics. 1999;2:5760.

4. Yoo, Hyung J. Geriatric Diseases and Medical Service for the Aged in Korea. J Korean Geriatr Soc. 1997;1:6-11.
5. Podichetty VK, Mazanec DJ, Biscup RS. Chronic non-malignant musculoskeletal pain in older adults: clinical issues and opioid intervention. Postgrad Med J. 2003;79:627-633.

6. Frondini C, Lanfranchi G, Minardi M, Cucinotta D. Affective, behavior and cognitive disorders in the elderly with chronic musculoskelatal pain: the impact on an aging population. Arch Gerontol Geriatr. 2007;44:167-171.

7. Muszalik M, Kornatowski T, Zielinska-Wieczkowska H, Kedziora-Kornatowska K, Dijkstra A. Functional assessment of geriatric patients in regard to healthrelated quality of life (HROoL). Clin Interv Aging. 2015;10:61-67.

8. Creamer P, Flores R, Hochberg MC. Management of osteoarthritis in older adults. Clin Geriatr Med. 1998;14:435-54.

9. Loeser $\mathrm{RF}, \mathrm{Jr}$. Aging and the etiopathogenesis and treatment of osteoarthritis. Rheum Dis Clin North Am. 2000;26:547-567.

10. Arendt-Nielsen L, Fernandez-de-Las-Penas C, Graven-Nielsen T. Basic aspects of musculoskeletal pain: from acute to chronic pain. J Man Manip Ther. 2011;19:186-193.

11. Dieppe P. Chronic musculoskeletal pain. BMJ. 2013;346:f3146.

12. Wewers ME, Lowe NK. A critical review of visual analogue scales in the measurement of clinical phenomena. Res Nurs Health. 1990;13:227-236.

13. Koçyiğit $H$, Aydemir Ö, Ölmez N, Memiş A. Kısa form-36 (KF-36)'nın Türkçe versiyonunun güvenilirliği ve geçerliliği. Ilaç ve tedavi dergisi. 1999;12:102106.

14. Ware JE, Jr., Sherbourne CD. The MOS 36-item short-form health survey (SF36). I. Conceptual framework and item selection. Med Care. 1992;30:473483.

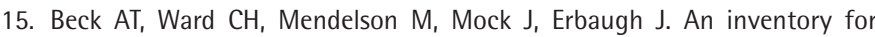
measuring depression. Arch Gen Psychiatry. 1961;4:561-571.

16. Hisli N. Beck Depresyon Envanterinin Geçerliği Üzerine Bir Çalışma. Turkish Journal of Psychology. 1988;6:118-126.

17. The World Health Organization Quality of Life Assessment (WHOOOL): development and general psychometric properties. Soc Sci Med. 1998;46:1569-1585.

18. de Haes JC, van Knippenberg FC. The quality of life of cancer patients: a review of the literature. Soc Sci Med. 1985;20:809-817.

19. Bränholm I, Eklund M, Fugl-Meyer KS, Fugl-Meyer AR. On work and life satisfaction. J Rehabil Sci. 1991;4:29-34.

20. van Campen C, ledema J. Are persons with physical disabilities who participate in society healthier and happier? Structural equation modelling of objective participation and subjective well-being. Qual Life Res. 2007; 16:635-645.

21. Skevington SM, Lotfy M, O'Connell KA, WHOQOL Group. The World Health Organization's WHOQOL-BREF quality of life assessment: psychometric properties and results of the international field trial. A report from the WHO0OL group. Quality of life Research. 2004;13:299-310.

22. Arslantaş D, Metintaş S, Ünsal A, Kalyoncu C. Eskişehir Mahmudiye ilçesi yaşılıarında yaşam kalitesi. Osmangazi Tıp Dergisi. 2006;28:81-89.

23. Harris L. Review of prevalence of pain in older adults. MMedSci Thesis: Keele University, 2004.

24. Yelin E, Herrndorf A, Trupin L, Sonneborn D. A national study of medical care expenditures for musculoskeletal conditions: the impact of health insurance and managed care. Arthritis Rheum. 2001;44:1160-1169.

25. Nouhi E, MehdipourRabari R, Abasszadeh A. Effect of intensity and location of local musculoskeletal pain on quality of life in elderly, Kerman, Iran. Bimonthly Journal of Hormozgan University of Medical Sciences. 2012;15:e88507.

26. Lee $\mathrm{SH}$, Yang SO. The effects of chronic musculoskeletal pain and depression on health-related quality of life by gender in community-dwelling older adults. Journal of Korean Academy of Community Health Nursing. 2010;21:21-30. 
27. Brown ST, Kirkpatrick MK, Swanson MS, McKenzie IL. Pain experience of the elderly. Pain Manag Nurs. 2011;12:190-196.

28. Smith AK, Cenzer IS, Knight SJ, Puntillo KA, Widera E, Williams BA, Boscardin WJ, Covinsky KE. The epidemiology of pain during the last 2 years of life. Ann Intern Med. 2010;153:563-539.

29. Woo J, Ho SC, Lau J, Leung PC. Musculoskeletal complaints and associated consequences in elderly Chinese aged 70 years and over. J Rheumatol. 1994;21:1927-1931.

30. Bergman $S$, Herrstrom P, Hogstrom K, Petersson IF, Svensson B, Jacobsson LT. Chronic musculoskeletal pain, prevalence rates, and sociodemographic associations in a Swedish population study. J Rheumatol. 2001;28:13691377.

31. Holland NW, Gonzalez EB. Soft tissue problems in older adults. Clinics in geriatric medicine. 1998;14:601-612.

32. Gowin KM. Diffuse pain syndromes in the elderly. Rheum Dis Clin North Am. 2000;26:673-682.

33. Cavalieri T. Pain management at the end of life. Clin Geriatrics. 2005;13:4452.

34. Ballentine NH. Polypharmacy in the elderly: maximizing benefit, minimizing harm. Critical care nursing quarterly. 2008;31:40-45.

35. D'Astolfo CJ, Humphreys BK. A record review of reported musculoskeletal pain in an Ontario long term care facility. BMC geriatrics. 2006;6:5.

36. Murphy SL, Dubin JA, Gill TM. The development of fear of falling among community-living older women: predisposing factors and subsequent fall events. J Gerontol A Biol Sci Med Sci. 2003;58:M943-7.
37. Graven-Nielsen T, Lund H, Arendt-Nielsen L, Danneskiold-Samsøe B, Bliddal H. Inhibition of maximal voluntary contraction force by experimental muscle pain: a centrally mediated mechanism. Muscle \&t Nerve: Official Journal of the American Association of Electrodiagnostic Medicine. 2002;26:708-712.

38. Leveille SG, Jones RN, Kiely DK, Hausdorff JM, Shmerling RH, Guralnik JM, Kiel DP, Lipsitz LA, Bean JF. Chronic musculoskeletal pain and the occurrence of falls in an older population. JAMA. 2009;302:2214-2221.

39. Soriano TA, DeCherrie LV, Thomas DC. Falls in the community-dwelling older adult: a review for primary-care providers. Clin Interv Aging. 2007;2:545554.

40. Whipple RH, Wolfson LI, Amerman PM. The relationship of knee and ankle weakness to falls in nursing home residents: an isokinetic study. J Am Geriatr Soc. 1987;35:13-20.

41. Kaya B. Yaşılık ve depresyon-I tanı ve değerlendirme. Turkish Journal of Geriatrics. 1999;2:72-82.

42. Miu DK, Chan TY, Chan MH. Pain and disability in a group of Chinese elderly out-patients in Hong Kong. Hong Kong Med J. 2004;10:160-165.

43. İlhan MN, Maral I, Kitapçı M, Aslan S, Çakır N, Bumin MA. Yaşlılarda depresif belirtiler ve bilişsel bozukluğu etkileyebilecek etkenler. Klinik Psikiyatri. 2006;9:177-184.

44. Copeland J, Dewey P, Saunders P. Yaşlılarda depresyon. Cev İncila Kaplan Türk Psikiyatri Dergisi. 1992;3:3-8.

45. Karahan AY, Sahin N, Baskent A. Comparison of effectiveness of different exercise programs in treatment of failed back surgery syndrome: A randomized controlled trial. J Back Musculoskelet Rehabil. 2017;30:109120. 